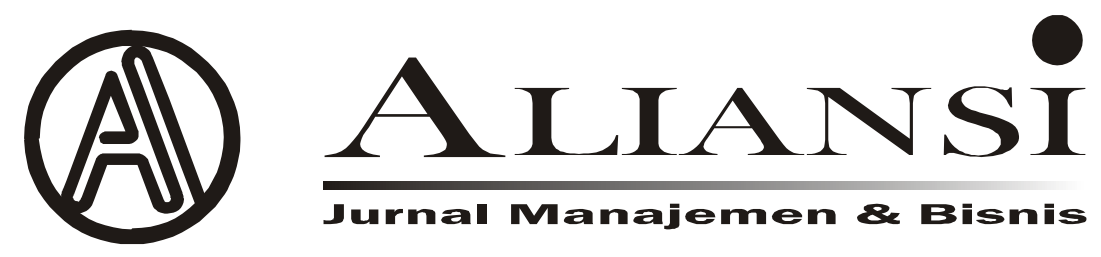

\title{
ANALISIS RASIO KEUANGAN TERHADAP PERUBAHAN LABA PADA PERUSAHAAN FARMASI
}

\author{
Oleh : Putri Sarirati dan Dewi Melani \\ email : putrisarirati@ stimaimmi.ac.id
}

\begin{abstract}
The purpose of this study is to determine the effect of the company's financial ratio empirically, both partially and simultaneously on changes in profit. The selection of samples was conducted by purposive sampling method from 12 company samples obtained by 9 company samples. The study used data analysis methods with multiple linear regressions and performed classical assumption tests first.

The results of this study showed that the Current Ratio variable partially had an influence and negatively on the change in profit. Based on the resultsof the t test witha $t$ count of $-3,341>$ fromthetable's $t$ value of $-2,030$ and a significance level of $0.002<0.05$. The Return on Assets variable partially has an effect and positives on the change in profit. Based on the resultsof the t test with at calculate of 12,978> ofthetable's t value of 2,030 and the significance level of $0.000<0.05$. While the Debt to Equity Ratio variable and the Total Assets Turnover variable partially had no significant effect on the change in profit. Simultaneous testing showed that variables Current Ratio, Return On Assets, Debt to Equity Ratio, and Total Assets Turnover simultaneously had a significant effect on changes in profits. Based on the results of the test $F$ with a significance value of $0.000<0.05$ and Fcalculated $46.745>$ from the table Fvalueof 2.61. The variable influence rate of Current Ratio, Return On Assets, Debt to Equity Ratio and Total Assets Turnover simultaneously is $82.4 \%$.

Keywords: Current Ratio (CR), Return On Assets (ROA), Debt to Equity Ratio (DER), Total Assets Turnover (TATO), and Change in Profit
\end{abstract}

\section{PENDAHULUAN}

Tujuan laporan keuangan yaitu memberikan informasi kepada para pemakainya untuk meramalkan, membandingkan, serta menilai kemampuan perusahaan untuk mendapatkan laba (Harahap, 2002). Laporan keuangan menggambarkan informasi yang menunjukkan posisi keuangan, hasil kinerja, serta perubahan posisi keuangan suatu perusahaan yang telah terjadi dan harapan di masa yang akan mendatang. Informasi yang didapat dari laporan keuangan biasanya digunakan oleh berbagai pihak baik pihak eksternal maupun internal perusahaan. Faktor pembatas disini adalah kemampuan sistem menyusun laporan keuangan untuk memberikan informasi yang diperlukan. Semakin baik informasi yang disusun, berarti semakin banyak informasi yang relevan yang dapat dihasilkan.

Menurut Dermawan Sjahrial (2013:37) menyatakan bahwa rasio likuiditas menggambarkan kemampuan perusahaan membayar kewajiban jangka pendek (utang lancar) pada saat jatuh tempo dengan menggunakan aktiva lancar. Berdasarkan pendapat diatas maka rasio likuiditas adalah rasio untuk mengukur kemampuan perusahaan untuk memenuhi kewajiban jangka pendek kepada kreditur yang harus segera dipenuhi.

Rasio solvabilitas digunakan untuk menjelaskan penggunaan utang untuk membiayai sebagian dari pada aktiva perusahaan. Pembiayaan oleh hutang mempunyai pengaruh terhadap perusahaan karena utang mempunyai beban bersifat tetap. Kegagalan perusahaan dalam membayar bunga atas utang dapat menyebabkan kesulitan keuangan yang berakhir pada kebangkrutan perusahaan. Tetapi penggunaan utang juga memberikan subsidi pajak atas bunga yang dapat menguntungkan pemegang saham. Karena itu penggunaan utang harus diseimbangkan antara keuntungan dan kerugiannya (Muslich, 2010).

\section{STUDI LITERATUR}

\section{Rasio Keuangan Yang Berpengaruh Terhadap Perubahan Laba}

Dari uraian diatas mengenai teori rasio keuangan yang telah dijelaskan maka dipilih 4 rasio keuangan yang mewakili dari setiap kelompok rasio yang digunakan sebagai variabel independen pada 
penelitian ini yang berpengaruh terhadap perubahan laba. Berikut ini penjelasan mengenai pemilihan rasio tersebut:

a. Rasio Likuiditas menjelaskan mengenai kemampuan perusahaan melunasi utang lancarnya ketika utang tersebut jatuh tempo di tahun berikutnya dengan menggunakan aktiva lancar yang dimiliki perusahaan (Brigham dan Houston, 2013:134).

b. Rasio Profitabilitas menjelaskan kemampuan perusahaan dalam menghasilkan laba baik dengan menggunakan seluruh aktiva yang ada maupun dengan modal sendiri (Kasmir, 2012:104). Semua rasio yang terdapat dalam kelompok rasio ini menjelaskan mengenai pencapaian laba perusahaan. Perusahaan menggunakan aktiva yang dimiliki dengan efektif kemungkinan besar perusahaan tersebut akan mendapatkan laba tinggi.

c. Rasio Solvabilitas merupakan rasio yang mengukur seberapa besar aktiva yang dimiliki perusahaan berasal dari hutang atau modal, sehingga dengan rasio tersebut dapat diketahui posisi perusahaan dan kewajibannya yang bersifat tetap (Brigham dan Houston 2013:133).

d. Rasio Aktivitas mengukur keefektifan perusahaan dalam menggunakan aktiva yang dimiliki (Brigham dan Houston, 2013:135).

Rasio yang dipilih untuk mewakili rasio aktivitas dalam penelitian ini adalah Total Assets Turnover, TATO yaitu rasio yang digunakan untuk mengukur perputaran aktiva yang dimiliki perusahaan dan mengukur jumlah penjualan yang diperoleh dari tiap rupiah aktiva.

\section{METODOLOGI}

\section{Analisis Regresi Berganda}

Analisis regresi berganda bertujuan untuk mengetahui ada atau tidaknya pengaruh variabel independen yaitu Current Ratio (CR), Return On Assets (ROA), Debt to Equity Ratio (DER), dan Total Assets Turnover (TATO) terhadap variabel dependen Perubahan Laba. Berikut ini adalah hasil analisis regresi berganda:

Tabel

Hasil Uji Regresi Berganda

Coefficients $^{\mathrm{a}}$

\begin{tabular}{|c|c|c|c|c|c|c|}
\hline \multicolumn{7}{|c|}{ Coefficients $^{\mathrm{a}}$} \\
\hline \multirow[b]{2}{*}{ Mode } & & \multicolumn{2}{|c|}{$\begin{array}{c}\text { Unstandardized } \\
\text { Coefficients }\end{array}$} & \multirow{2}{*}{$\begin{array}{c}\text { Standardized } \\
\text { Coefficients } \\
\text { Beta }\end{array}$} & \multirow[b]{2}{*}{$\mathrm{T}$} & \multirow[b]{2}{*}{ Sig. } \\
\hline & & $\mathrm{B}$ & Std. Error & & & \\
\hline \multirow[t]{5}{*}{1} & (Constant) & 5,846 & 36,903 & & ,158 & ,875 \\
\hline & $C R$ &,- 336 & , 101 &,- 319 & $-3,341$ & ,002 \\
\hline & ROA & 7,591 & ,585 & ,942 & 12,978 & ,000 \\
\hline & DER &,- 126 & ,128 &,- 122 &,- 985 & ,332 \\
\hline & TATO & ,325 & ,252 & 130 & 1,289 & ,206 \\
\hline
\end{tabular}

Berdasarkan tabel diatas pada kolom Unstandardizen Coeffiecients bagian B diperoleh model persamaan regresi linear berganda yaitu: $\mathrm{Y}=5,846-0,336 \mathrm{CR}+7,591 \mathrm{ROA}-0,126 \mathrm{DER}+$ 0,325 TATO

Dari persamaan diatas diketahui konstantan sebesar 5,846 menyatakan bahwa jika Current Ratio bernilai nol $(\mathrm{CR}=0)$, Return On Assets bernilai nol $(\mathrm{ROA}=0)$, Debt to Equity Ratio bernilai nol $(\mathrm{DER}=0)$, dan Total Assets Turnover bernilai nol (TATO=0) maka nilai perubahan laba sebesar 5,846. Current ratio (CR) mempunyai koefisien regresi sebesar 0,336 menyatakan bahwa setiap penambahan $1 \%$ Current Ratio (dengan asumsi bahwa nilai koefisien variabel lain tetap atau tidak berubah) maka akan menurunkan perubahan laba sebesar 0,336. Namun sebaliknya, jika Current Ratio turun 1\% (dengan asumsi bahwa nilai koefisien variabel lain tetap atau tidak berubah) maka perubahan laba diprediksis mengalami peningkatan sebesar 0,336.

Return On Assets (ROA) mempunyai koefisien regresi sebesar 7,591 menyatakan bahwa setiap penambahan 1\% Return On Assets (dengan asumsi bahwa nilai koefisien variabel lain tetap atau tidak berubah) maka akan menaikan perubahan laba sebesar 7,591. Namun sebaliknya, jika Return On Assets turun $1 \%$ (dengan asumsi bahwa nilai koefisien variabel lain tetap atau tidak berubah) maka akan menurunkan laba sebesar 7,591.

Debt to Equity Ratio (DER) mempunyai koefisien regresi sebesar -0,126 menyatakan bahwa setiap penambahan 1\% Return On Assets (dengan asumsi bahwa nilai koefisien variabel lain tetap atau tidak berubah) maka akan menurunkan perubahan laba sebesar 0,126. Namun sebaliknya jika Debt to Equity Ratio turun 1\% (dengan asumsi bahwa nilai koefisien variabel lain tetap atau tidak berubah) maka perubahan laba diprediksi mengalami kenaikan sebesar 0,126 .

Total Assets Turnover (TATO) mempunyai koefisien regresi sebesar 0,325 menyatakan bahwa setiap penambahan 1\% Total Assets Turnover (dengan asumsi bahwa nilai koefisien variabel lain tetap atau tidak berubah) maka akan menaikkan perubahan laba sebesar 0,325. Namun sebaliknya, jika Total Assets Turnover turun 1\% (dengan asumsi bahwa nilai koefisien variabel lain tetap atau tidak berubah) maka akan menurunkan perubahan laba sebesar 0,325. 


\section{PENGUJIAN HIPOTESIS}

\section{Pengujian Individu atau Parsial (Uji t)}

Untuk mengetahui apakah variabel independen dalam model regresi berpengaruh terhadap variabel dependen, maka dilakukan pengujian dengan uji $\mathrm{t}(t$ test). Menurut Imam Ghozali (2011:101) jika nilai Sig. $<0,05$ maka artinya variabel independen $(\mathrm{X})$ secara parsial berpengaruh terhadap variabel dependent (Y). Ada empat hipotesis yang akan diuji dengan uji t.

H1: rasio likuiditas (Current Ratio) berpengaruh signifikan terhadap perubahan laba.

$\mathrm{H} 2$ : rasio profitablilitas (Return On Assets) berpengaruh signifikan terhadap perubahan laba.

H3: rasio leverage (Debt to Equity Ratio) berpangaruh signifikan terhadap perubahan laba.

H4: rasio aktivitas (Total Assets Turnover) berpengaruh signifikan terhadap perubahan laba.

Uji t ini dilakukan dengan membandingkan signifikansi thitung dengan ketentuan:

a. Jika thitung < ttabel pada á 0,05 , maka $\mathrm{Ha}$ ditolak dan $\mathrm{HO}$ diterima.

b. Jika thitung > ttabel pada á 0,05, maka $\mathrm{Ha}$ diterima dan $\mathrm{HO}$ ditolak.

Tabel

Hasil Uji Hipotesis Secara Parsial Coefficients $^{\mathrm{a}}$

\begin{tabular}{|c|c|c|c|c|c|c|}
\hline \multirow{2}{*}{\multicolumn{2}{|c|}{ Model }} & \multicolumn{2}{|c|}{$\begin{array}{c}\text { Unstandardized } \\
\text { Coefficients }\end{array}$} & \multirow{2}{*}{$\begin{array}{c}\begin{array}{c}\text { Standardized } \\
\text { Coefficients }\end{array} \\
\text { Beta }\end{array}$} & \multirow[b]{2}{*}{ T } & \multirow[b]{2}{*}{ Sig. } \\
\hline & & $B$ & Std. Error & & & \\
\hline \multirow[t]{5}{*}{1} & (Constant) & 5,846 & 36,903 & & , 158 & 875 \\
\hline & $\mathrm{CR}$ &,- 336 & , 101 &,- 319 & $-3,341$ & ,002 \\
\hline & ROA & 7,591 & ,585, & 942 & 12,978 & ,000 \\
\hline & DER &,- 126 & 128 &,- 122 & -985 & ,332 \\
\hline & TATO & ,325 & ,252 & ,130 & 1,289 & 206 \\
\hline
\end{tabular}

Sumber: SPSS 23

Dari uji t yang telah dilakukan, diperolah nilai ttabel sebesar 2,030. Dari hasil uji t yang disajikan pada tabel dapat diketahui pengaruh masing-masing variabel independen terhadap variabel dependen.

a. Current Ratio (X1) mempunyai nilai signifikansi sebesar $0,002<0,05$ artinya signifikan, sedangkan nilai thitung diperoleh $-3,341>$ dari nilai ttabel sebesar -2,030. Hasil ini berarti $\mathrm{Ha}$ diterima dan $\mathrm{HO}$ ditolak. Artinya Current Ratio berpengaruh terhadap Perubahan Laba. Hal ini berarti Hipotesis 1 diterima.

b. Return On Assets (X2) mempunyai nilai signifikansi sebesar $0,000<0,05$ artinya signifikan, sedangkan nilai thitung diperoleh $12,978>$ dari nilai ttabel sebesar 2,030. Hasil ini berarti $\mathrm{Ha}$ diterima dan $\mathrm{HO}$ ditolak. Artinya Return On Assets berpengaruh terhadap
Perubahan Laba. Hal ini berarti Hipotesis 2 diterima.

c. Debt to Equity Ratio (X3) mempunyai nilai signifikansi sebesar 0,332>0,05 artinya tidak signifikan, sedangkan nilai thitung diperoleh $0,985<$ dari nilai ttabel sebesar $-2,030$. Hasil ini berarti $\mathrm{Ha}$ ditolak dan $\mathrm{HO}$ diterima. Artinya Debt to Equity Ratio tidak berpengaruh terhadap Perubahan Laba. Hal ini berarti Hipotesis 3 ditolak.

d. Total Assets Turnover (X4) mempunyai nilai signifikansi sebesar 0,206>0,05 artinya tidak signifikan, sedangkan nilai thitung diperoleh 1,289 < dari nilai ttabel sebesar 2,030. Hasil ini berarti $\mathrm{Ha}$ ditolak dan $\mathrm{HO}$ diterima. Artinya Total Assets Turnover tidak berpengaruh terhadap Perubahan Laba. Hal ini berarti Hipotesis 4 ditolak.

\section{Pengujian Menyeluruh atau Simultan (Uji F)}

Secara simultan, pengujian hipotesis dilakukan dengan uji $\mathrm{F}$ ( $F$ test). Uji $\mathrm{F}$ dilakukan untuk menguji apakah variabel-variabel independen berpengaruh secara simultan terhadap variabel dependen. Berdasarkan nilai signifikan menurut Imam Ghozali (2011:101) jika nilai Sig. < 0,05 maka artinya variabel independen $(\mathrm{X})$ secara simultan berpengaruh terhadap dependen $(\mathrm{Y})$. Adapun hipotesis untuk uji F adalah sebagai berikut:

H5: Current Ratio, Return On Assets, Debt to Equity Ratio, dan Total Assets Turnover secara simultan berpengaruh terhadap perubahan laba.

Uji ini dilakukan dengan membandingkan signifikansi Fhitung dengan ketentuan:

a. Jika Fhitung < Ftabel pada á 0,05 maka $\mathrm{Ha}$ ditolak dan $H 0$ diterima

b. Jika Fhitung > Ftabel pada á 0,05 maka $\mathrm{Ha}$ diterima dan $H 0$ ditolak.

Setelah uji $\mathrm{F}$ dilakukan, maka diperoleh nilai Fhitung dan nilai signifikansi.

Tabel

Hasil Uji Hipotesis Secara Simultan

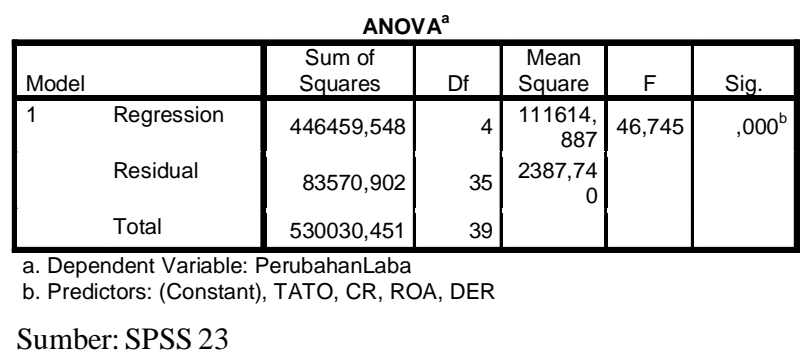


Menurut imam ghozali (2011:101) jika nilai sig. < 0,05 maka artinya variabel independen (x) secara simultan berpengaruh terhadap variabel dependen (y). Dari uji ANOVA (Analysis of Varians) atau uji $\mathrm{F}$ menunjukkan bahwa nilai Sig. 0,000. Karena nilai Sig. $<0,05$ maka dapat disimpulkan bahwa variabel CR, ROA, DER, dan TATO secara simultan berpengaruh terhadap perubahan laba.

Berdasarkan nilai hitung dan tabel menurut V. Wiratna Sujarweni (2014:154) jika nilai Fhitung > Ftabel maka artinya variabel independen (X) secara simultan berpengaruh terhadap variabel dependent (Y). Rumus mencari Ftabel $=(\mathrm{k} ; \mathrm{n}-\mathrm{k})=(4 ; 40-4)=$ $(4 ; 36)=2,61$

Karena Fhitung sebesar 46,745 sedangkan $F$ tabel sebesar 2,61 yang artinya Fhitung lebih besar dari $F$ tabel jadi $H$ a diterima dan $H 0$ ditolak. Maka dapat disimpulkan bahwa CR, ROA, DER, dan TATO secara simultan berpengaruh terhadap Perubahan Laba.

\section{Uji Koefisien Determinasi $\left(R^{2}\right)$}

Nilai koefisien korelasi (R) menunjukkan seberapa besar korelasi atau hubungan antara variabel-variabel independen dengan variabel. Koefisien korelasi dikatakan kuat jika nilai $\mathrm{R}$ berada di atas 0,5 dan mendekati nilai 1 . Koefisien determinasi $\left(R^{2}\right)$ menunjukkan seberapa besar variabel independen menjelaskan variabel dependennya. Nilai $R$ square adalah nol sampai dengan satu. Apabila nilai $R$ square semakin mendekati satu, maka variabel-variabel independen memberikan semua informasi yang dibutuhkan untuk memprediksi variasi variabel dependen. Sebaliknya, semakin kecil nilai $R$ square, maka kemampuan variabel-variabel independen dalam menjelaskan variasi dependen semakin terbatas. Nilai $R$ square memiliki kelemahan yaitu nilai $R$ square akan meningkat setiap ada penambahan satu variabel independen meskipun variabel independen tersebut tidak berpengaruh signifikan terhadap variabel dependen. Oleh karena itu, digunakan nilai adjusted $R$ square untuk mengevaluasi mana model regresi terbaik.

Tabel

Hasil Uji Koefisien Determinasi Model Summary ${ }^{\mathrm{D}}$

\begin{tabular}{|l|r|r|r|r|}
\hline Model & $\mathrm{R}$ & $\begin{array}{c}\mathrm{R} \\
\text { Square }\end{array}$ & $\begin{array}{c}\text { Adjusted } \\
\text { R Square }\end{array}$ & $\begin{array}{r}\text { Std. Error of } \\
\text { the Estimate }\end{array}$ \\
\hline 1 &, $918^{\mathrm{a}}$ &, 842 &, 824 & 48,864507 \\
\hline
\end{tabular}

a. Predictors: (Constant), TATO, CR, ROA, DER

b. Dependent Variable: PerubahanLaba

Sumber: SPSS 23
Pada model summary di atas, dapat dilihat hasil analisis regresi secara keseluruhan. Dimana nilai $\mathrm{R}$ sebesar 0,918 yang menunjukkan bahwa korelasi atau hubungan antara perubahan laba (variabel dependen) dengan current ratio, return on asets, debt to equity ratio, dan total assets turnover (variabel independen) mempunyai tingkat hubungan yang sangat kuat yaitu sebesar 91,8\%. Tingkat hubungan yang sangat kuat ini dapat dilihat dari tabel pedoman untuk memberikan interprestasi koefisien korelasi.

Nilai Adjustted $R$ Square adalah sebesar 0,824. Angka ini mengidentifikasikan bahwa perubahan laba (variabel dependen) mampu dijelaskan oleh current ratio, return on assets, debt to equity ratio, dan total assets turnover (variabel independen) sebesar $82,4 \%$ atau pengaruh variabel CR, ROA, DER dan TATO secara simultan adalah $82,4 \%$. sedangkan selebihnya sebesar $17,6 \%$ dijelaskan oleh sebabsebab lain. Kemudian standard error of the estimate adalah sebesar 48,864507 dimana semakin kecil angka ini akan membuat model regresi semakin tepat dalam memprediksi perubahan laba.

\section{Interprestasi Hasil}

Tingkat pengaruh variabel Current Ratio (X1) terhadap Perubahan Laba (Y) berpengaruh dan negatif, tingkat pengaruh variabel Return On Assets (X2) terhadap Perubahan Laba (Y) berpengaruh dan positif, tingkat pengaruh variabel Debt to Equity Ratio (X3) terhadap Perubahan Laba tidak berpengaruh signifikan, dan variabel Total Assets Turnover (X4) terhadap perubahan laba tidak berpengaruh signifikan. Berpengaruh negatif maksudnya adalah semakin meningkat nilai CR maka semakin menurun perubahan laba. Sedangkan jika berpengaruh positif maksudnya semakin meningkat nilai ROA maka akan semakin meningkatkan perubahan laba.

\section{KESIMPULAN}

Secara parsial, variabel current ratio memiliki pengaruh yang signifikan dan negatif terhadap perubahan laba. Hal ini dibuktikan dengan menggunakan uji t dengan thitung sebesar -3,341 > dari nilai ttabel sebesar 2,030 dan tingkat signifikansi sebesar $0,002<0,05$. Variabel return on assets memiliki pengaruh yang signifikan dan positif terhadap perubahan laba. Hal ini dibuktikan dengan menggunakan uji t dengan thitung sebesar 12,978 > dari nilai ttabel sebesar 2,030 dan tingkat signifikansi sebesar $0,000<0,05$. Variabel debt to equity ratio 
tidak berpengaruh signifikan terhadap perubahan laba. Hal ini dibuktikan dengan menggunakan uji $\mathrm{t}$ dengan thitung sebesar $-0,985<$ dari nilai tabel sebesar -2,030 dan tingkat signifikansi sebesar 0,332 $>0,05$. Variabel total assets turnover tidak berpenngaruh signifikan terhadap perubahan laba. Hal ini dibuktikan dengan menggunakan uji t dengan thitung sebesar 1,289 < dari nilai ttabel sebesar 2,030 dan tingkat signifikansi sebesar 0,206>0,05.

Secara simultan, hasil penelitian ini menunjukkan bahwa variabel Current Ratio, Return On Assets, Debt to Equity Ratio, dan Total Assets Turnover secara bersama-sama berpengaruh secara signifikan terhadap perubahan laba. Hal ini dibuktikan dengan menggunakan uji $\mathrm{F}$ dengan nilai signifikansi sebesar $0,000<0,05$ dan Fhitung sebesar 46,745 > dari nilai Ftabel sebesar 2,61.

\section{PENUTUP DAN AGENDA PENELITIAN KE DEPAN}

Sebagai bahan pertimbangan untuk pengembangan penelitian selanjutnya adalah untuk menggunakan sampel yang lebih banyak dengan karakteristik yang lebih beragam dari berbagai sektor dan memperpanjang periode penelitian agar tercipta distribusi data yang lebih baik, dan jumlah rasio diperbanyak agar dapat membandingkan dengan penelitian sebelumnya.

\section{Referensi}

Agustin \& Syahria, S (2019). Analisis Current Ratio dan Cash Ratio Dalam Mengukur Return On Assets Pada PT Mestika Mandiri Medan. Repository Universitas Dharmawangsa, (Online), (http://repository.dharmawangsa.ac.id/ 305/7/BAB\%20II_15510061.pdf, diakses 12 Juli 2021).

Agustina \& Silvia (2012). Pengaruh Rasio Keuangan Terhadap Perubahan Laba Pada Perusahaan Manufaktur yang Terdaftar di Bursa Efek Indonesia. Jurnal Wira Ekonomi Mikroskil : JWEM, (Online), Vol 2, No.2, (https:// www.mikroskil.ac.id/ejurnal/index.php/jwem/ article/view/152/105, diakses 14 Juli 2021).

Ardiany, R.D. (2019). Analisis Pengaruh Rasio Keuangan Terhadap Perubahan Laba Pada Perusahaan Manufaktur yang Terdaftar di Bursa Efek Indonesia. Skripsi. Jember : Fakultas Ekonomi dan Bisnis Universitas Jember.

Astuti, I.M.J. (2013). Analisis Pengaruh Rasio Keuangan Terhadap Perubahan Laba Pada
Perusahaan Real Estate and Property dan Transportation Services yang Terdaftar di Bursa Efek Indonesia. Skripsi. Surakarta : Fakultas Ekonomi dan Bisnis Universitas Muhammadiyah Surakarta.

ekonomibisnis.com

Fatimah, S (2014). Analisis Pengaruh Rasio Keuangan Terhadap Perubahan Laba Pada Perusahaan Manufaktur Sektor Aneka Industri yang Terdaftar di Bursa Efek Indonesia. Skripsi. Tanjung Pinang : Fakultas Ekonomi Universitas Maritim Raja Ali Haji.

Fitria, M (2014). Analisis Pengaruh Rasio Keuangan Terhadap Perubahan Laba Pada Perusahaan Manufaktur Sektor Industri Barang Konsumsi yang Terdaftar di Bursa Efek Indonesia Tahun 2007-2011. Skripsi. Surakarta : Fakultas Ekonomi dan Bisnis Universitas Muhammadiyah Surakarta.

https://www.idx.co.id/

Hutapea, A.W. Saerang, I.S. \& Tulung, J.E. (2017). Pengaruh Retun On Assets, Net Profit Margin, Debt to Equity Ratio, dan Total Assets Turnover Terhadap Harga Saham Industri Otomotif dan Komponen yang Terdaftar di Bursa Efek Indonesia. Jurnal EMBA, 17 (02) : 541-552.

Idnfinancial.com

Ifada, L.M. \& Puspitasari, T (2016). Analisis Pengaruh Rasio Keuangan Terhadap Perubahan Laba. Jurnal Akuntansi \& Auditing, 16 (1) : 97-108.

Indriastuti, N (2014). Analisis Rasio Keuangan Terhadap Perubahan Laba Pada Perusahaan Industri Barang Konsumsi yang Terdaftar di Bursa Efek Indonesia Periode 2010-2011. Skripsi. Surakarta : Fakultas Ekonomi dan Bisnis Universitas Muhammadiyah Surakarta.

Maris, K (2016). Pengaruh Total Assets Turnover dan Return On Investment Terhadap Harga Saham. Skripsi. Bandung : Fakultas Ekonomi dan Bisnis Universitas Komputer Indonesia.

Merzieana, N.I (2016). Pengaruh Debt to Equity Ratio dan Return On Assets Terhadap Dividen Payout Ratio. Skripsi. Bandung : Sekolah Tinggi Ilmu Ekonomi.

Ningsih, L.S. (2014). Analisis Pengaruh Rasio Keuangan Terhadap Perubahan Laba Pada Perusahaan Asuransi yang Terdaftar di Bursa Efek Indonesia. Skripsi. Surakarta : Fakultas Ekonomi dan Bisnis Universitas Muhammdiyah Surakarta. 